\title{
Attachment of Pasteuria penetrans Endospores to Meloidogynespp. Juveniles Affected by Temperatures and the Nematode species
}

Myoung Rae Cho*, Hyung Hwan Kim, Taek Joon Kang, Seung Joon Ahn, Chang Yul Yang and Sung Wook Jeon

Horticultural \& Herbal Crop Environment Division, National Institute of Horticultural \& Herbal Science, RDA, Suwon 441-440, Korea

\section{선충기생세균(Pasteuria penetrans) 내생포자의 뿌리혹선충[Meloidogyne spp.] 유충 부착에 대한 온도와 선충종의 영향}

\author{
조명래* · 김형환 · 강택준 · 안승준 · 양창열 · 전성욱 \\ 국립원예특작과학원 원예특작환경과
}

\begin{abstract}
A greenhouse soil infested with an obligate nematode parasitic bacterium, Pasteuria penetrans, was used to test the effect of temperatures on the endospore attachment to root-knot nematode, Meloidogyne arenaria, juveniles (J2). Freshly hatched J2s were inoculated to the soil in petri dish and incubated under different temperatures of $20^{\circ} \mathrm{C}, 25^{\circ} \mathrm{C}, 30^{\circ} \mathrm{C}$, and $35^{\circ} \mathrm{C}$ for 7 days. The endospore attachment rates were $100 \%$ in all the temperatures, while the number of endospores attached per $\mathrm{J} 2$ was highest in $25^{\circ} \mathrm{C}$ with 28.3 endospores/J2 followed by $20.2,18.6$, and 13.6 in $30^{\circ} \mathrm{C}, 20^{\circ} \mathrm{C}$, and $35^{\circ} \mathrm{C}$, respectively. When the soil was pre-treated under different temperatures before the $\mathrm{J} 2$ inoculation, the endospore attachment rates significantly decreased from $60 \%$ in room temperature to $25.0,31.7,8.3,5.0$, and $0 \%$ after the soil incubation in $-30^{\circ} \mathrm{C}, 4^{\circ} \mathrm{C}, 40^{\circ} \mathrm{C}, 50^{\circ} \mathrm{C}$, and $100^{\circ} \mathrm{C}$ for 10 days, respectively. The endospore numbers attached per $\mathrm{J} 2$ were $3.5,4.3,1,1$, and 0 when the soil was pre-treated in $-30^{\circ} \mathrm{C}, 4^{\circ} \mathrm{C}, 40^{\circ} \mathrm{C}, 50^{\circ} \mathrm{C}$, and $100^{\circ} \mathrm{C}$, respectively, which were lower than $5.3 / \mathrm{J} 2$ of room temperature treated soil. The $P$. penetrans isolate in the soil showed nematode species-specific endospore attachment characteristics with $100 \%$ attachment rate only on $M$. arenaria $\mathrm{J} 2 \mathrm{~s}$ while the rates were $0 \%$ on $M$. hapla and M. incognita $\mathrm{J} 2 \mathrm{~s}$.
\end{abstract}

Key words: Pasteuria penetrans, Root-knot nematode, Meloidogyne arenaria, biological control, endospore

초 록: 선충절대기생세균(Pasteuria penetrans)이 감염되어 있는 온실토양을 이용하여 세균의 내생포자가 땅콩뿌리혹선충(Meloidogyne arenaria) 유충 표면에 부착하는데 대한 온도의 영향에 대해 시험하였다. 갓 부화된 뿌리혹선충 2령충(J2)을 페트리디쉬 내의 토양에 접종한 후 $20^{\circ} \mathrm{C}, 25^{\circ} \mathrm{C}, 30^{\circ} \mathrm{C}, 35^{\circ} \mathrm{C}$ 에서 7 일간 처리하였다. 모든 온도에서 내생포자의 $\mathrm{J} 2$ 부착률은 모두 $100 \%$ 로 나타났으나 J2당 내생포자 부착수는 $25^{\circ} \mathrm{C}$ 에서 28.3 개로 가장 많았으며 $30^{\circ} \mathrm{C}, 20^{\circ} \mathrm{C}$ 및 $35^{\circ} \mathrm{C}$ 에서 각각 $\mathrm{J} 2$ 당 $20.2,18.6$ 및 13.6 개로 낮아졌다. $\mathrm{J} 2$ 를 접종하기 전에 세균이 있는 토양을 온도 별로 10 일간 전처리하였을 때 내생포자 부착률은 실온에서의 $60 \%$ 에 비해 $-30^{\circ} \mathrm{C}, 4^{\circ} \mathrm{C}, 40^{\circ} \mathrm{C}, 50^{\circ} \mathrm{C}$ 및 $100^{\circ} \mathrm{C}$ 에서 각각 $25.0,31.7,8.3,5.0$ 및 $0 \%$ 로 현저하게 낮아졌다. J2 당 내생포자 부착수도 실온에서의 5.3 개에 비해 $-30{ }^{\circ} \mathrm{C}, 4{ }^{\circ} \mathrm{C}, 40^{\circ} \mathrm{C}, 50^{\circ} \mathrm{C}$ 및 $100{ }^{\circ} \mathrm{C}$ 에서 각각 $3.5,4.3,1,1,0$ 개로 적 었다. P. penetrans 세균의 내생포자를 뿌리혹선충 종별로 $\mathrm{J} 2$ 에 부착 시험한 결과 땅콩뿌리혹선충에서는 $100 \%$ 였으나 당근뿌리혹선충 $(M$. hapla)과 고구마뿌리혹선충(M. incognita)에서는 모두 $0 \%$ 로 본 균주는 뿌리혹선충 종에 대해 기주선호성을 가진 것으로 나타났다.

검색어: Pasteuria penetrans, 뿌리혹선충, Meloidogyne arenaria, 생물적방제, 내생포자

Pasteuria penetrans (Thorne) Sayre \& Starr has been recognized as one of the most promising biological agents for the control of

*Comesponding author: mrchook@korea.kr

Received February 28 2013; Revised March 272013

Accepted March 292013 root-knot nematodes (Sayre and Starr., 1989; Stirling., 1984). $P$. penetrans is widely distributed throughout the world and contributes natural control of nematodes, especially of root-knot nematodes (Chen and Dickson, 1998). P. penetrans is gram-positive bacterium and has various characteristics desirable for a biological control agent against plant-parasitic nematodes (Dickson and 
Oostendorp, 1990). The endospores can survive under adverse environmental conditions such as humidity, desiccation, high and low temperature, and absence of host nematodes for a long period (Dickson et al., 1994). Storage of $P$. penetrans for 11 years did not reduce the ability of the endospores to attach $\mathrm{m}$ to juveniles of $M$. javanica (Giannakou et al., 1997).

$P$. penetrans could reduce yield losses caused by $M$. incognita $23-24 \%$ for tobacco and $38-55 \%$ for winter vetch in two years experiments (Brown et al., 1985). In Korea, occurrence of $P$. penetrans was reported from various plant-parasitic nematode species of Meloidogyne spp., Helicotylenchus sp., Pratylenchus sp., Heterodera sp., and Aphelenchus sp. (Cho et al., 2005a). The Korean isolates of $P$. penetrans also showed promising control effects on major root-knot nematodes (Yu et al., 2003; Zhu et al., 2005; Park et al., 2005). P. penetrans 98-35 isolate showed control effect of $92 \%$ on $M$. arenaria in a pot test (Cho et al., 2000).

The characteristic of $P$. penetrans as an obligate nematode parasite is a major limiting factor in using the bacterium for biological control of nematodes (Williams et al., 1989; Cho et al., 2005b). Artificially cultured $P$. penetrans was already commercialized, however, the product was not successful in effectively managing Belonolaimus longicaudatus on golf course turf (Crow et al., 2011).

For mass production of $P$. penetrans, it is important to understand the endospore attachment characteristics to the juveniles of root-knot nematodes (Freitas et al., 1997). The endospores attach to the cuticle of a nematode and a penetration tube develops which penetrates the nematode. Host adhesion of the endospore is one of the most critical steps in completion of the life-cycle (Chen and Dickson, 1998).

This study was conducted to understand the effects of temperatures and root-knot nematode species on attachment of the endospores to root-knot nematode juveniles.

\section{Materials and Methods}

Pasteuria penetrans infested soil was collected at an oriental melon (Cucumis melo var. Makuwa, Makino) greenhouse in Seongju-county, Kyungsangbook-do, Korea in 1998. The plant debris and large particles in the soil were removed by sieving through $3 \mathrm{~mm}$-diameter sieve and stored in a plastic bucket and covered with plastic film in room temperature before it was used for the experiments.

Meloidogyne arenaria (Neal) Chitwood was collected from roots of oriental melon (Cucumis melo var. Makuwa, Makino) in Seongju-county, Kyungsangbook-do and maintained on tomato (Lycopersicon esculentum Mill. cv. Young-gwang) roots in greenhouse at National Institute of Horticultural \& Herbal Science, Suwon, Korea. The juveniles (J2s) were collected from the tomato roots by combining Hussey and Barker's method and Baermann funnel method. The J2s not older than three days after hatching were used in the experiment.

\section{Effects of temperature on $P$. penetrans endospore attachment to $M$. arenaria juveniles}

The soil was put in $87 \times 15 \mathrm{~mm}$ plastic petri dishes. Each petri dish containing $50 \mathrm{~g}$ soil was inoculated with $3,000 \mathrm{~J} 2$ in $15 \mathrm{cc}$ distilled water. The inoculated petri dishes were sealed with parafilm. The dishes were put in incubators set at different temperatures of $20^{\circ} \mathrm{C}, 25^{\circ} \mathrm{C}, 30^{\circ} \mathrm{C}$, and $35^{\circ} \mathrm{C}$. Each treatment was replicated 3 times.

After 7 days, the $\mathrm{J} 2 \mathrm{~s}$ were recovered from the petri dishes by combined sieving and centrifugal sugar flotation method. The recovered $\mathrm{J} 2 \mathrm{~s}$ were examined under inverted microscope (Zeiss, Axiovert 135) to check the endospore attachment and count the endospore numbers per $\mathrm{J} 2$ on 20 individuals from each dish.

To check the presence of live J2s in the test soil, 3 petri dishes inoculated with $15 \mathrm{cc}$ distilled water were incubated in $25^{\circ} \mathrm{C}$. From the soil inoculated with distilled water only, no J2 was recovered. Statistical analysis was done using SAS program.

\section{Effects of $P$. penetrans infested soil pre-exposure temperatures on the endospore attachment to $M$. arenaria juveniles}

The $P$. penetrans infested soil used in this test was the same soil as described above. The soil was stored in a plastic container under room temperature for 15 months until this experiment.

The plastic petri dishes containing the $50 \mathrm{~g}$ soil and sealed with parafilm were incubated for 10 days in different temperatures of $-30{ }^{\circ} \mathrm{C}, 4^{\circ} \mathrm{C}, 40^{\circ} \mathrm{C}, 50^{\circ} \mathrm{C}$ and room temperature. Glass petri dishes containing $50 \mathrm{~g}$ soil and sealed with aluminum foil were incubated in $100^{\circ} \mathrm{C}$ dry oven for 8 hours. After incubations in the different temperature conditions, the petri dishes were inoculated with 3,000 $\mathrm{J} 2 \mathrm{~s}$ each as described above. The dishes were incubated in $25^{\circ} \mathrm{C}$ for 3 days. The $\mathrm{J} 2 \mathrm{~s}$ were recovered and examined as described above. 


\section{P. penetrans endospore attachment to 3 Meloidogyne species juveniles}

The soil infested with $P$. penetrans was tested for endospore attachment to juveniles of different Meloidogyne species. M. incognita was collected from roots of oriental melon in Seongju and maintained on tomato (Lycopersicon esculentum Mill. cv. Young-gwang). M. hapla, collected from peony (Paeonia lactiflora Pall.) root at Euisung, Korea, was maintained on tomato (L. esculentum Mill. cv. Seo-gwang). The soil infested with $P$. penetrans was prepared and the $\mathrm{J} 2 \mathrm{~s}$ of the three species including M. arenaria were inoculated as described above. Attachment rates and endospore numbers were examined after incubation at $25^{\circ} \mathrm{C}$ for 3 days.

\section{Results and Discussions}

\section{Effects of temperature on $P$. penetrans endospore attachment to $M_{\text {. arenaria juveniles }}$}

Attachment rates and numbers of Pasteuria penetrans endospores to Meloidogyne arenaria juvenile (J2) showed significant difference affected by the incubation temperatures. Among the four incubation temperatures tested, the endospore numbers attached per $\mathrm{J} 2$ were highest at $25^{\circ} \mathrm{C}$ with $28.3 / \mathrm{J} 2$ followed by $30^{\circ} \mathrm{C}, 20^{\circ} \mathrm{C}$, and $35^{\circ} \mathrm{C}$ (Table 1). In the all temperatures, all the $\mathrm{J} 2 \mathrm{~s}$ were encumbered with at least one endospore.

Hatz and Dickson (1992) reported that the optimum temperature for attachment was $30^{\circ} \mathrm{C}$ when $M$. arenaria and $P$. penetrans infested soil were incubated for 24 hours at $10^{\circ} \mathrm{C}, 20^{\circ} \mathrm{C}, 30^{\circ} \mathrm{C}$, and $35^{\circ} \mathrm{C}$. In the report, incubation in temperature of $25^{\circ} \mathrm{C}$ was not included. In our results, the optimum temperature for the endospore attachment was $25^{\circ} \mathrm{C}$, and this result confirms the regression model of Freitas et al., (1997) presenting the maximum attachment would occur when $\mathrm{J} 2$ and the endospores were incubated at approximately $25^{\circ} \mathrm{C}$.

\section{Effects of $P$. penetrans infested soil pre-exposure temperatures on the endospore attachment to $M$. arenaria juveniles}

The Pasteuria penetrans infested soil pre-exposure to above lethal temperatures significantly lowered the endospore attachment (Table 2). Soil pre-exposure to high temperatures of $40^{\circ} \mathrm{C}$ and $50^{\circ} \mathrm{C}$ significantly reduced the endospore attachment numbers up to $1 / \mathrm{J} 2$ which was much lower than 5.3/J2 of room temperature. Attachment rates also decreased to 8.3 and $5.0 \%$ in $40^{\circ} \mathrm{C}$ and $50^{\circ} \mathrm{C}$, respectively, while that of room temperature was $60 \%$. After the soil pre-exposure to $100^{\circ} \mathrm{C}$ for 8 hours, endospore attachment did not occur. In contrast to the high temperature exposure, effects of the soil pre-exposure to lower temperatures on the endospore attachment were not that significant.

The attachment rates were 25 and $31.7 \%$ after soil pre-exposure at $-30{ }^{\circ} \mathrm{C}$ and $4{ }^{\circ} \mathrm{C}$, respectively, while that of room temperature was $60 \%$ (Table 2). The endospore numbers per J2 also showed slight decrease to 3.5 and $4.3 / \mathrm{J} 2$ while that of room temperature was 5.3/J2. Freitas et al. (1997) also observed the decreased endospore attachment rate after endospore encumbered soil pre-exposure at $50^{\circ} \mathrm{C}$ and higher. Dutky and Sayre (1978) observed that there was no endospore attachment after $P$. penetrans infested soil exposed to $130^{\circ} \mathrm{C}$ for 1 hour. Giannakou et al. (1997) showed that preheating $P$. penetrans spores to above normal temperatures $\left(60^{\circ} \mathrm{C}\right)$ significantly increased attachment but reduced infection to $M$. javanica $\mathrm{J} 2 \mathrm{~s}$. These results showed that higher temperatures were more fatal to the vitality of $P$. penetrans endospores than lower temperatures. And our results showed that the $P$. penetrans in the infested soil stored for 15 months under room temperature still maintained its ability to attach to root-knot nematode $\mathrm{J} 2 \mathrm{~s}$ although the endospore

Table 1. Pasteuria penetrans endospore attachment to Meloidogyne arenaria juveniles (J2) affected by incubation temperatures*

\begin{tabular}{ccccc}
\hline \multirow{2}{*}{ Endospore attachment } & \multicolumn{4}{c}{ Incubation temperatures } \\
\cline { 2 - 5 } & $20^{\circ} \mathrm{C}$ & $25^{\circ} \mathrm{C}$ & $30{ }^{\circ} \mathrm{C}$ & $35^{\circ} \mathrm{C}$ \\
\hline $\begin{array}{c}\text { No. of endospores attached/J2 } \\
\text { (Min.-Max. } \pm \text { STD)** }\end{array}$ & $18.6 \mathrm{bc}$ & $28.3 \mathrm{a}$ & $20.2 \mathrm{~b}$ & $13.6 \mathrm{c}$ \\
Attachment rate (\%) & $(2.7-40.0 \pm 10.9)$ & $(10-51.3 \pm 10.5)$ & $(2.7-41.0 \pm 10.6)$ & $(2.3-32.3 \pm 8.6)$ \\
& $100 \mathrm{a}$ & $100 \mathrm{a}$ & $100 \mathrm{a}$ & $100 \mathrm{a}$ \\
\hline
\end{tabular}

* M. arenaria J2s were inoculated to the bacterium infested soil and incubated for 7 days.

** Data are means of 3 replications of 20 juveniles. Means within a row followed by the same letter are not significantly different according to Duncan's multiple rage test $(\mathrm{P} \leq 0.05)$. 
Table 2. Pasteuria penetrans endospore attachment to Meloidogyne arenaria juveniles inoculated to the bacterium infested soil pre-exposed at different temperatures

\begin{tabular}{ccccccc}
\hline \multirow{2}{*}{ Endospore attachment } & \multicolumn{5}{c}{ Soil pre-treatment temperatures } \\
\cline { 2 - 7 } & $-30{ }^{\circ} \mathrm{C}$ & $4{ }^{\circ} \mathrm{C}$ & Room T. & $40{ }^{\circ} \mathrm{C}$ & $50{ }^{\circ} \mathrm{C}$ & $100^{\circ} \mathrm{C}$ \\
\hline No. of endospores attached/J2 & $3.5 \mathrm{ab}$ & $4.3 \mathrm{a}$ & $5.3 \mathrm{a}$ & $1 \mathrm{bc}$ & $1 \mathrm{bc}$ & $0 \mathrm{c}$ \\
(Min.-Max. $\pm \mathrm{STD})^{*}$ & $(0-13 \pm 3.3)$ & $(0-10 \pm 2.8)$ & $(0-16 \pm 4.8)$ & $(0-12 \pm 2.6)$ & $(0-2 \pm 0.4)$ & $(0-0 \pm 0)$ \\
Attachment rate (\%) & $25 \mathrm{bc}$ & $31.7 \mathrm{c}$ & $60.0 \mathrm{a}$ & $8.3 \mathrm{~cd}$ & $5.0 \mathrm{~d}$ & $0.0 \mathrm{~d}$ \\
\hline
\end{tabular}

* Data are means of 3 replicates of 20 juveniles examined. Means within a row followed by the same letter are not significantly different according to Duncan's multiple rage test $(P \leq 0.05)$.

Table 3. Pasteuria penetrans endospore attachment to three Meloidogyne species juveniles after incubation for 3 days at $25^{\circ} \mathrm{C}$

\begin{tabular}{cccc}
\hline \multirow{2}{*}{ Endospore attachment } & \multicolumn{3}{c}{ Meloidogyne species } \\
\cline { 2 - 4 } & M. arenaria & M. hapla & M. incognita \\
\hline No. of endospores attached/J2 & 56.7 & 0 & 0 \\
(Min.-Max. \pm STD)* & $(17-118 \pm 30.8)$ & 0 & 0 \\
Attachment rate (\%) & 100 & 0
\end{tabular}

* Data are means of 20 juveniles.

attachment rates and numbers were lower than those of the first experiment (Table 1 and 2).

\section{P. penetrans endospore attachment to 3 Meloidogyne species juveniles}

Attachment rates and numbers of Pasteuria penetrans endospores to Meloidogyne arenaria juvenile were $100 \%$ and $56.7 / \mathrm{J} 2$. However, there was no endospore attached to the $\mathrm{J} 2 \mathrm{~s}$ of $M$. hapla and $M$. incognita (Table 3). Different endospore attachment among P. penetrans isolates on Meloidogyne spp. and Pratylenchus sp. (Oostendorp et al., 1990) and variation in host ranges of $P$. penetrans from California, U.S.A. and Australia were demonstrated (Stirling, 1985). The endospores of U.S.A. isolate were readily attached to $M$. javanica, $M$. incognita and M. hapla, but three $P$. penetrans populations from Australia were more specialized. Our result indicates that the $P$. penetrans used in this experiment has very high host specification with $M$. arenaria.

The above experiment results showed that the $P$. penetrans endospore attachment to root-knot nematode juvenile is more feasible in $25^{\circ} \mathrm{C}$ condition than in other temperatures. And the soil pre-treatment in lower and higher than room temperature greatly reduced the attachment of the endospores to the root-knot nematode juveniles. And the $P$. penetrans showed its host specific endospore attachment only on M. arenaria. This information on the temperature effects on endospore attachments and the host specificity of $P$. penetrans used in this study would be useful for a development of mass production system of $P$. penetrans and practical use of the bacterium for biological control of root-knot nematodes in the future.

\section{Acknowledgement}

This study was partly supported by research fund (PJ0083412013) from Rural Development Administration, Republic of Korea.

\section{Literature Cited}

Brown, S.M., Kepner, J.L., Smart, G.C., 1985. Increased crop yield following application of Bacillus penetrans to field plot infested with Meloidogyne incognita. Soil Biol. Biochem. 17, 483-486.

Chen, Z.X., Dickson, D.W., 1998. Review of Pasteuria penetrans: biology, ecology, and biological control potential. J. Nematol. 30, 313-340.

Cho, M.R, Na, S.Y., Yiem, M.S., 2000. Biological control of Meloidogyne arenaria by Pasteuria penetrans. J. Asia-Pacific Entomol. 3, 71-76

Cho, M.R., Yiem, M.S., Jeon, H.Y., Han, H.R., Kim, H.H., Na, S.Y., Lim, C.K., 2005a. Occurrence of Pasteuria spp. associated with plant-parasitic nematodes in Korea. J. Asia-Pacific Entomol. 8, 193-197.

Cho, M.R., Dickson, D.W., Hewlett, T.E., 2005b. Comparison of inoculation methods, Meloidogyne spp. and different host plants for production of Pasteuria penetrans. J. Asia-Pacific Entomol. 8, 297-300 
Crow, W.T., Luc, J.E., Giblin Davis., R.M., 2011. Evaluation of Econem, a formulated Pasteuria sp. bionematicide, for management of Belonolaimus longicaudatus on golf course turf. J. Nematol. 43, 101-109.

Dickson, D.W., Oostendorp, M., 1990. Biological control of nematodes with Pasteuria spp. Nematology Circular 175. Fla. Dept. Agric. \& Consumer Serv., Division of Plant Industry.

Dickson, D.W., Oostendorp, M., Giblin-Davis, R., Mitchell, D.J., 1994. Control of plant-parasitic nematodes by biological antagonists, in: Rosen, D., Bennett, F.D., Capinera, J.L. (Eds.), Pest management in the subtropics. Biological control: A Florida perspective. Andover, pp. 575-601.

Dutky, E.M., Sayre, R.M., 1978. Some factors affecting infection of nematodes by the bacterial spore parasite Bacillus penetrans. J. Nematol. 10, 285(Abstr.).

Freitas, L.G., Mitchell, D.J., Dickson, D.W., 1997. Temperature effects on the attachment of Pasteuria penetrans endopsores to Meloidogyne arenaria race 1. J. Nematol. 29, 547-555.

Giannakou, I.O., Pembroke, B., Gowen, S.R., Davis, K.G., 1997. Effects of long term storage and above normal temperatures on spore adhesion of Pasteuria penetrans and infection of the root-knot nematode Meloidogyne javanica. Nematologica 43, 185-192.

Hatz, B., Dickson, D.W., 1992. Effects of temperature on attachment, development, and interactions of Pasteuria penetrans on Meloidogyne arenaria. J. Nematol. 24, 512-521.
Oostendorp, M., Dickson, D.W., Mitchell, D.J., 1990. Host range and ecology of isolates of Pasteuria spp. from the Southeastern United States. J. Nematol. 22, 525-531.

Park, D.S., Zhu, Y.Z., Cho, M.R., Hur, J.H., Lim, C.K., 2005. Effect of temperature and $\mathrm{pH}$ on attachment of Pasteuria penetrans to Meloidogyne arenaria and the mass production. Korean J. Pesti. Sci. 9, 268-273.

Sayre, R.M., Starr, M.P., 1989. Genus Pasteuria Metchnikoff, 1888, in: Williams, S.T., Sharpe, M.E., Holt, J.G. (Eds.), Bergey's manual of systematic bacteriology, The Williams \& Wilkins, Baltimore, pp. 2601-2615.

Stirling, G.R., 1984. Biological control of Meloidogyne javanica with Bacillus penetrans. Phytopathol. 74, 55-60.

Stirling, G.R., 1985. Host specificity of Pasteuria penetrans within the Genus Meloidogyne. Nematologica 31, 203-209.

Williams, A.B., Stirling, G.R., Hayward, A. C., Perry, J., 1989. Properties and attempted culture of Pasteuria penetrans, a bacterial parasite of root-knot nematode (Meloidogyne javanica). J. Appl. Bact. 67, 145-156.

Yu, Y.M., Cho, M.R., Zhu, Y.Z., Park, D.H., Hur, J.H., Lim, C.K., 2003. Suppression of Meloidogyne incognita in lettuce and oriental melon by Pasteuria penetrans KW1. Plant Pathol. 19, 177-180.

Zhu, Y.Z., Park, D.S., Cho, M.R., Hur, J.H., Lim, C.K., 2005. Suppression of Meloidogyne arenaria by different treatments of Pasteuria penetrans. Korean J. Pesti. Sci. 9, 437-441. 